Research letter

\title{
Practice patterns in prescribing oral care products by dental practitioners
}

\author{
Alena B. Abdrashitova, Rinat A. Saleev, Linara T. Musina \\ Kazan State Medical University, Kazan, Russia
}

Received 2 November 2016, Revised 30 December 2016, Accepted 13 February 2017

(C) 2016, Abdrashitova A.B., Saleev R.A., Musina L.T.

(C) 2016, Russian Open Medical Journal

\begin{abstract}
This paper describes the practice patterns of dental practitioners in how they choose oral care products for prescriptions to their patients. One hundred seventy-three respondents were selected for a medico-sociological study. They were divided into 3 groups based on their work experience: less than 5 years (30.0\%), 5-9 years (40.0\%) and 10-14 years (30.0\%). The majority of respondents were dental therapists $(71.0 \%)$, and the rest were paedodontists, dental surgeons, periodontists and orthodontists $(11.0 \%, 7.0 \%, 4.0 \%$ and $1.0 \%$, respectively). The study was conducted using a questionnaire specially developed by us, which consisted of 34 questions grouped into several domains. Analysis of the obtained results has shown that the majority of dental practitioners (88.7\%) were competent in prescribing oral care products. Professionals with work experience over 10 years often choose oral care products incorrectly; $80.6 \%$ of them believe that long-term use of personal oral care products containing antiseptic components affects the oral microbial flora, which suggests that it is necessary to amend the existing classification of toothpastes.
\end{abstract}

Keywords: oral hygiene, personal hygiene products, toothpastes

Cite as Abdrashitova AB, Saleev RA, Musina LT. Practice patterns in prescribing oral care products by dental practitioners. Russian Open Medical Journal 2017; 6: e0208

Correspondence to Alena B. Abdrashitova. Address: Apt 35, 13, Meridiannaya str., 420095, Kazan, Russia. Tel.: +7-917-854-5125.

E-mail: egorova-alena@mail.ru

\section{Introduction}

Prevention of dental diseases is one of the most important tasks of health workers. One of the most popular preventive measures for development of dental diseases is a personal oral hygiene [1]. Personal oral hygiene program should be based on the following principles: total individualization; development of oral self-care skills corresponding to the dental and oral hygiene status of each patient; case monitoring and control of program execution [2]. The development of an effective oral care program is aimed at improving and maintaining the condi-tion of oral cavity and prevention of incidence and progression of dental diseases. To achieve this task, the dental practitioner must be fully informed of oral care products with numerous va-rieties of them available on the market [3-5].

Currently, the toothpastes contain two antiseptics: chlorhexidine and triclosan. The latter component may be present in two forms: combined with Gantrez system (copolymer of polyvinylmethyl ether and maleic anhydride) and as a single agent [6]. The antiseptics contained in toothpastes may have bacteriostatic (by suppressing the assimilation of indispensable amino acids by microorganisms) and bactericidal (by disorganizing the cytoplasmic cell membrane of microbes) properties against gram-positive and gram-negative bacteria, dermatophytes and yeasts [7]
Available literature shows the possibility of such antiseptics' influence on oral microflora [8, 9]. However, the duration of exposure and its effect on dental and microbiological state of patients have not been studied. In addition, we did not find any data on the level of dentists' competence regarding the prescription of personal oral care products to their patients in the available foreign literature.

Research objective was to study the competence of dental practitioners at prescribing personal oral care products.

\section{Material and Methods}

One hundred seventy-three respondents with experience of less than 5 years $(30.0 \%), 5-9$ years $(40.0 \%)$ and $10-14$ years (30.0\%) were selected for medico-sociological study. The majority of respondents were dental therapists $(71 \%)$, paedodontists (11.0\%), dental surgeons (7.0\%), periodontists (4.0\%) and orthodontists $(1.0 \%)$. The majority $(78 \%)$ of the respondents worked in public institutions, the rest (22\%) worked in private health care organizations.

The study was conducted by using a specially developed questionnaire, which consisted of 34 questions divided into several domains (Appendix 1). Each domain was designed to evaluate the following aspects: 
i) level of professional competence of dental practitioners at prescribing personal oral care products to the patients;

ii) practice patterns of dental practitioners in prescribing the antiseptic-containing toothpastes to the patients.

\section{Results and Discussion}

The dental practitioners use personal oral care products themselves, recommend them to their family members and prescribe them to patients. Our research has shown that the majority of respondents prefer four brands among the wide range of personal oral care products on the market: Sensodyne (toothpaste with sodium fluoride and potassium chloride, which has a pronounced anti-caries and anti-hypersensitivity effect) (34.0\%), Parodontax (toothpaste with herbal ingredients Echinacea, myrrh, chamomile, sage, mint, rhatany - for treatment of periodontal diseases) (25.0\%), Lacalut (toothpaste with chlorhexidine for treatment of periodontal diseases with recommended course of application) (22.0\%), Blend-a-med (chamomile, sage, eucalyptus) (16.0\%). Other 15 brands of oral care products were mentioned in no more than $1.0 \%$ of all cases. Oral care products listed above have a wide range of indications for prescription; they are widely advertised in mass media, although they belong to a high price category.

Composition was a key factor for the majority of respondents (93.8\%) when prescribing oral care products. They are mostly interested in fluorine (33.1\%) and mineral content (25.6\%). Oral care products are often prescribed to provide anti-caries (25.1\%) and anti-inflammatory (20.3\%) effects, as well as to solve several problems simultaneously (18.6\%). Thus, the composition of oral care products and their effect on organs of oral cavity are important for most dental practitioners.

Analysis of questionnaires has shown that $62.4 \%$ of respondents prescribe oral care products based on individual indications and $38.1 \%$ do not consider them, and the rest found it difficult to answer this question. As we see it, this situation is related to a wide range of oral care products with multiple effects being present on the market. However, it should be noted that in various conditions of oral cavity some components of oral care products have a positive effect, while others can affect negatively.

The second domain of questionnaire is related to prescription of antiseptic oral care products. Thirty-four percent of respondents indicated that antiseptics may be contained in toothpastes, $48 \%$ - In mouthwashes, $10 \%$ - in flosses, $85 \%$ - in chewing gums, despite the last two statements being incorrect. The low frequency of correct answers is apparently related to the fact that products of only certain brands contain antiseptics.

The questionnaire included questions on specific types of antiseptics, namely chlorhexidine and triclosan. Currently, chlorhexidine is the most well-known of them; it is contained in oral care products under Lacalut brand, which was preferred by $47.3 \%$ of respondents. At the same time, it was shown that dental practitioners find it difficult to name the brands of personal oral care products which contain chlorhexidine. We observed the same situation when analyzing answers to questions in triclosandedicated domain. Despite the fact that $52.4 \%$ of respondents preferred it, they still found it difficult to name a brand of oral care products with this component. Currently, antiseptic toothpastes belong to therapeutic category and are recommended for continuous use [10]. The opinions of dental practitioners on this issue are shown follow.

The dental practitioners' awareness of toothpaste category was follow: theraupetic $-45 \%$, theraupetic and preventive $-41 \%$, hygienic $-12 \%$, cannot say $-2 \%$.

The dental practitioners' opinions on the duration of antiseptic toothpastes use were as follows: $1-4$ weeks $-76 \%$, up to 6 months $-19 \%$, up to year $-1 \%$, constantly $-0 \%$, cannot say $-4 \%$.

Despite the current classification of oral care products, the dental practitioners point out the necessity of its revision and inclusion of antiseptics to the therapeutic category. The obtained results reflect drawbacks of the existing classification, namely the notion that these hygiene preparations belong to the therapeutic category and can be used not only with therapeutic purpose, but also preventively and, therefore, without restrictions. Analysis of this situation has shown that dental practitioners believe that duration of oral care products use (42.4\%), allergy (18.2\%), indications (16.3\%) and impact on the oral flora (12.1\%) are the main limitations of antiseptic-containing oral care products. The majority of respondents (85.9\%) noted that prolonged use of antiseptic oral care products may lead to disruption of the oral microbial flora, so it is recommended to use them for no more than 1-4 weeks.

The dental practitioners' opinions regarding the indications for use of antiseptic toothpastes were following:
i) at acute periodontal diseases $-40 \%$,
ii) at chronic periodontal diseases $-21 \%$,
iii) at oral mucosa diseases $-29 \%$,
iv) at caries $-9 \%$,
v) at hyperesthesia $-1 \%$.

Analyzing the answers of dental practitioners regarding the indications for use of antiseptic-containing toothpastes, it was found that in most cases the respondents considered acute periodontal diseases to be the primary indication for prescribing antiseptic toothpastes, which is the most correct answer. However, some doctors answered this question incorrectly.

As a part of this study, we found that $76.0 \%$ of dental practitioners believe that oral care products with antiseptic (triclosan) may affect the oral microflora; $81.0 \%$ of respondents stated that the same effect is observed with chlorhexidine. The obtained results are likely to be related to the opinion of the dental practitioners on the effect of antiseptics on oral mucosa.

\section{Conclusion}

Most dental practitioners (88.7\%) showed a high level of professional competence at prescribing personal oral care products. Most commonly, the persons with work experience over 10 years show incompetence in prescribing them. The obtained results confirm the need for teaching in-depth knowledge of composition, mechanism of action, indications, duration and limitations of toothpastes at the post-diploma educational courses for dental practitioners based on recent data concerning the effect of antiseptics on the oral microflora.

According to $80.6 \%$ of respondents, prolonged use of antiseptic oral care products has an impact on oral microbial flora, indicating the need for separation of oral care products for therapeutic and for preventive purposes. 
Conflict of interest: none declared.

\section{References}

1. Ulitovsky SB, Alekseeva ES, Kalinina OV. Oral hygiene preparations as a motivation of dental health. Parodontologiya 2011; 16(2): 65-66. Russian

2. Garanina TS. The role of personal oral hygiene in the treatment of generalized periodontitis. Molodoy Uchenyy 2014; (3): 155-157. Russian

3. Kopetsky IS, Pobozhyeva LV. Modern treatment products for personal oral hygiene. Lechebnoe Delo 2012; (3): 29-32. Russian

4. Akulovich AV, Suetenkov DE, Yalyshev RK, Konovalova AYu, Novak MO. Assessment of efficiency of use of calcium hydroxyapatite hygiene preparations for tooth enamel sensitivity reduction. Stomatologiya Detskogo Vozrasta i Profilaktika 2015; 14(4): 41-44. Russian

5. Islamova DM, Valeev IV, Bulgakova Al. The justification for Sensodyne ${ }^{\circledR}$ use in dental hyperesthesia treatment. Stomatologiya dlya Vsekh 2015; (4): 10-12. Russian

6. Urazova RZ, Musina LT, Egorova AB. A comparative analysis of antiseptic toothpastes. Practical Medicine 2009; (1): 84-86. Russian
7. Troyanenko LI, Chumakova YuG. Comparative evaluation of therapeutic action of toothpastes on model of periodontitis in rats. Vestnik Stomatologii 2014; (3): 9-14. Russian

8. Musina LT, Egorova AB, Urazova RZ. Influence of tooth paste antiseptics on the oral mikroflora. Kazan Medical Journal 2010; 91(4): 525-528. Russian

9. Mikhalchenko DV, Fedotova YuM, Mikhalchenko VF, Dimitrova MS, Veremeenko TV, Baklanova A.A. The effectiveness of asepta and listerine total care therapeutic-preparations at inflammatory periodontal diseases treatment. Mezhdunarodnyy Zhurnal Prikladnykh i Fundamental'nykh Issledovaniy 2016; (3-1): 83-86. Russian

10. Ulitovsky SB. Modern trends of toothpaste market development. Forum Praktikuyushchikh Stomatologov 2012; (5): 12. Russian

\section{Authors:}

Alena B. Abdrashitova - MD, PhD, Associate Professor, Department of Pediatric Dentistry, Kazan State Medical University, Kazan, Russia.

Rinat A. Saleev - MD, DSc, Dean of Faculty of Dentistry, Kazan State Medical University, Kazan, Russia.

Linara T. Musina - MD, DSc, Professor of Department of Microbiology, Kazan State Medical University, Kazan, Russia. 
Appendix 1. The medico-sociological questionnaire for dental practitioners (page 1)

1. Your profession:
$\square$ Dental Therapist
$\square$ Prosthodontist
$\square$ Periodontist
$\square$ Orthodontist
$\square$ Dental Surgeon
$\square$ Paedodontist
2. Your experience:
3. Where do you work?
$\square$ in a public institution
$\square$ in a private dental clinic
4. When buying toothpaste, which ingredients do
you pay attention to?
$\square$ fluorine
$\square$ mineral components
$\square$ bleaching agents
$\square$ antiseptics
$\square$ enzymes
$\square$ phytocomponents
$\square$ your option

5. Do you prescribe oral care products for prevention of dental diseases to your patients?

$\square$ yes

$\square$ no

$\square$ cannot say

6. Do you think that there are limitations for using toothpastes with antiseptic components?

$\square$ yes, I think so

$\square$ no, I don't think so

$\square$ never thought about it

7. If yes, what are those limitations in your opinion?

8. To which group of toothpastes would you ascribe the antiseptic toothpastes?

$\square$ hygienic toothpastes

$\square$ therapeutic pastes

$\square$ dental treatment pastes

$\square$ cannot say

9. Do you think that prolonged use of antiseptic toothpastes can lead to the violation of the oral cavity microflora?

$\square$ yes, I think

$\square$ no, I don't think

$\square$ never thought about it

10. How do you think, which oral care products may contain antiseptics?

$\square$ toothpaste

$\square$ chewing gum

$\square$ oral rinse

$\square$ dental floss

$\square$ other (specify any)

\section{Which means of topical oral care do you} prescribe to your patients to prevent dental diseases?

$\square$ coating the teeth with fluoride varnish

$\square$ gels

$\square$ electrophoresis with minerals

$\square$ phonophoresis with minerals

$\square$ Diplen film

$\square$ other option

12. What determines your choice of toothpaste?

(you can select multiple positions)

$\square$ anti-caries properties

$\square$ whitening effect

$\square$ anti-inflammatory properties

$\square$ satisfactory price

$\square$ antibacterial properties

$\square$ brand loyalty

$\square$ ability to reduce gum bleeding

$\square$ combination of several of these effects

$\square$ interaction with brand representatives

$\square$ ability to reduce dental hypersensitivity

$\square$ your option

13. Do the members of your family use one toothpaste?

$\square$ yes

$\square$ no

14. Do you believe that toothpaste with triclosan may affect the microflora of the oral cavity?

$\square$ yes, I think so

$\square$ no, I don't think so

$\square$ never thought about it

15. Do you pay attention to the composition of the toothpaste when it is selected?

$\square$ yes

$\square$ no

$\square$ cannot say

16. Which criteria do you use when you prescribe antiseptic toothpaste to your patients?

$\square$ anti-inflammatory effect

$\square$ antibacterial effect

$\square$ whitening effect

$\square$ anti-caries effect

$\square$ reducement of dental hypersensitivity

$\square$ your option

17. Do children and adults in your family use the same toothpaste?

$\square$ yes

$\square$ no

18. What means of systemic action do you prescribe to your patients to prevent dental diseases?

$\square$ intake of trace elements (fluorine)

$\square$ intake of macroelements (calcium, phosphorus)

$\square$ adaptogenic drugs

$\square$ vitamins
19. What toothpaste do you use?

$\square$ Blend-a-med 7 Complete (oak bark, herbs)

$\square$ Blend-a-med (propolis)

$\square$ Blend-a-med (chamomile, sage, eucalyptus, oak bark)

$\square$ Blend-a-med (chamomile)

$\square$ Colgate Total 12

$\square$ Lacalut line

Parodontax

$\square$ Sensodyne

$\square$ New Zhemchug Total

$\square$ New Zhemchug with Laminaria extract

$\square$ Aquafresh

$\square$ Synquel

$\square$ Rocs

$\square$ Glister

$\square$ Other (specify any)

20. How long have you been using this toothpaste?

$\square 1$ month

$\square 2$ months

$\square$ 2-4 weeks

$\square$ other

21. Do you have stomatopathy at present?

$\square$ no

$\square$ I have:

$\square$ caries

$\square$ acute periodontal diseases

$\square$ chronic periodontal diseases

$\square$ oral mucosa diseases

$\square$ hypersensitivity of dental tissues

$\square$ other

22. Do you think that toothpaste with chlorhexidine can affect the oral microflora?

$\square$ yes, I think so

$\square$ no, I don't think so

$\square$ never thought about it

23. Do you think that toothpaste with triclosan can be used continuously for an unlimited period of time?

$\square$ yes

$\square$ no

$\square$ cannot say

24. Do you/Did you use a toothpaste with triclosan?

$\square$ yes

$\square$ no

$\square$ cannot say

25. For how long did you use a toothpaste with triclosan?

26. For how long do you recommend to use antiseptic toothpastes?

$\square$ 1-4 weeks

$\square$ up to 6 months

$\square$ up to 1 year

$\square$ permanent use 
Appendix 1. The medico-sociological questionnaire for dental practitioners (page 2)

27. If you are approached by a patient with acute periodontal inflammation, which toothpaste would you recommend?

$\square$ Blend-a-med 7 Complete (oak bark, herb)

$\square$ Blend-a-med (propolis)

$\square$ Blend-a-med (chamomile, sage, eucalyptus, oak bark)

$\square$ Blend-a-med (chamomile)

$\square$ Colgate Total 12

$\square$ Lacalut line

$\square$ Parodontax

$\square$ Sensodyne

$\square$ New Zemchug Total

$\square$ Aquafresh

$\square$ New Zemchug with Laminaria extract

$\square$ Synquel

$\square$ Rocs

$\square$ Glister

$\square$ Other (specify any)

28. Which triclosan-containing toothpastes do you usually recommend to your patients?

Blend-a-med 7 Complete (oak bark, herb)

$\square$ Blend-a-med (propolis)

$\square$ Blend-a-med (chamomile, sage, eucalyptus, oak bark)

$\square$ Blend-a-med (chamomile)

$\square$ Colgate Total 12

$\square$ Lacalut line

$\square$ Parodontax

$\square$ Sensodyne

$\square$ New Zemchug Total

$\square$ Aquafresh

$\square$ New Zemchug with Laminaria extract

$\square$ Synquel

$\square$ Rocs

$\square$ Glister

$\square$ Other (specify any)
29. If you are approached by a patient with chronic periodontitis in remission, which

toothpaste would you recommend?

Blend-a-med 7 Complete (oak bark, herb)

口 Blend-a-med (propolis)

$\square$ Blend-a-med (chamomile, sage, eucalyptus, oak bark)

$\square$ Blend-a-med (chamomile)

$\square$ Colgate Total 12

$\square$ Lacalut line

$\square$ Parodontax

$\square$ Sensodyne

$\square$ New Zemchug Total

$\square$ Aquafresh

$\square$ New Zemchug with Laminaria extract

$\square$ Synquel

$\square$ Rocs

$\square$ Glister

$\square$ Other (specify any)

30. If you are approached by a patient with high caries activity, which toothpaste would you recommend?

Blend-a-med 7 Complete (oak bark, herb)

Blend-a-med (propolis)

$\square$ Blend-a-med (chamomile, sage, eucalyptus, oak bark)

$\square$ Blend-a-med (chamomile)

$\square$ Colgate Total 12

$\square$ Lacalut line

$\square$ Parodontax

$\square$ Sensodyne

$\square$ New Zemchug Total

$\square$ Aquafresh

$\square$ New Zemchug with Laminaria extract

$\square$ Synquel

$\square$ Rocs

Gliste

$\square$ Other (specify any)

31. When do you recommend your patients to use antiseptic toothpaste?

$\square$ in case of acute periodontal diseases

$\square$ in case of chronic periodontal diseases

$\square$ in case of oral mucosa diseases

$\square$ in case of caries

$\square$ in case of hyperesthesia
32. Which toothpastes containing chlorhexidine do you usually recommend to your patients?

Blend-a-med 7 Complete (oak bark, herb)

$\square$ Blend-a-med (propolis)

$\square$ Blend-a-med (chamomile, sage, eucalyptus, oak bark)

$\square$ Blend-a-med (chamomile)

$\square$ Colgate Total 12

$\square$ Lacalut line

$\square$ Parodontax

$\square$ Sensodyne

$\square$ New Zemchug Total

$\square$ Aquafresh

$\square$ New Zemchug with Laminaria extract

$\square$ Synquel

$\square$ Rocs

$\square$ Glister

$\square$ Other (specify any)

33. Which antiseptics do you prefer as a component of oral care products?

$\square$ triclosan

$\square$ chlorhexidine

$\square$ calcium glycerophosphate

$\square$ cetylpyridium chloride

34. Which antiseptic-containing toothpaste do you usually recommend to your patients?

Blend-a-med 7 Complete (oak bark, herb)

$\square$ Blend-a-med (propolis)

$\square$ Blend-a-med (chamomile, sage, eucalyptus, oak bark)

$\square$ Blend-a-med (chamomile)

$\square$ Colgate Total 12

$\square$ Lacalut line

$\square$ Parodontax

$\square$ Sensodyne

$\square$ New Zemchug Total

$\square$ Aquafresh

$\square$ New Zemchug with Laminaria extract

$\square$ Synquel

$\square$ Rocs

$\square$ Glister

$\square$ Other (specify any) 